\title{
ANALISIS DAMPAK PROGRAM TERAPI HIV-AIDS PADA MODEL PENYEBARAN PENYAKIT HIV-AIDS DENGAN POPULASI TERBUKA
}

\author{
Feri Harianto, Evi Noviani, Yudhi
}

\begin{abstract}
INTISARI
Saat ini bagi penderita HIV-AIDS belum ditemukan vaksin maupun obat yang dapat menyembuhkan penyakit HIV-AIDS. Meskipun demikian penderita HIV-AIDS dapat melakukan suatu terapi dengan obat $A R V$ untuk meningkatkan sistem kekebalan pada tubuh yang telah terinfeksi, memperlambat fase terinfeksi HIV menjadi AIDS, dan mencegah kematian akibat infeksi oportunistik. Total populasi $(N)$ pada model matematika penyebaran penyakit HIV-AIDS dibagi menjadi empat subpopulasi, yaitu susceptible (S) atau negatif HIV, infected (I) atau positif HIV, treatment (T) atau terapi HIV-AIDS, dan AIDS patients (A) atau orang dengan HIV-AIDS (ODHA). Analisis pada model matematika menghasilkan dua titik kesetimbangan, yaitu titik kesetimbangan bebas penyakit $\left(\mathbf{E}_{1}\right)$ dan titik kesetimbangan endemik penyakit $\left(\mathbf{E}_{2}\right)$, kemudian dari titik kesetimbangan endemik penyakit selanjutnya menghasilkan angka reproduksi efektif $\left(R_{I}\right)$. Analisis kestabilan dari sistem pada titik kesetimbangan $\mathbf{E}_{1}$ stabil asimtotik ketika $R_{I}<1$, namun sistem pada titik kesetimbangan $\mathbf{E}_{2}$ stabil asimtotik ketika $R_{I}>1$. Simulasi model matematika pada model ini menunjukkan bahwa terapi yang diberikan pada penderita penyakit HIVAIDS berpengaruh positif dalam mempertahankan jumlah subpopulasi negatif HIV, memperlambat penyebaran infeksi, serta mengurangi jumlah subpopulasi positif HIV, subpopulasi ODHA, dan kematian akibat HIV-AIDS.
\end{abstract}

Kata kunci: HIV-AIDS, titik kesetimbangan, angka reproduksi efektif, kestabilan

\section{PENDAHULUAN}

Human Immunodeficiency Virus (HIV) merupakan virus yang dapat menurunkan dan menghancurkan sistem kekebalan tubuh sehingga orang yang terinfeksi HIV akan rentan terhadap penyakit. Apabila tubuh seseorang positif terinfeksi HIV maka perlu waktu lima sampai sepuluh tahun infeksi tersebut menjadi penyakit AIDS. AIDS (Acquired Immunodeficiency Syndrome) merupakan suatu penyakit yang muncul akibat infeksi HIV pada tubuh manusia [1].

Terapi dengan obat ARV yang selanjutnya akan disebut sebagai terapi HIV-AIDS, hingga saat ini merupakan terapi terbaik bagi orang-orang yang telah terinfeksi HIV. Menurut World Health Organization (WHO) pada tahun 2015 obat ARV sudah digunakan pada 46\% pasien HIV di berbagai negara, kemudian telah mengurangi angka kematian akibat penyakit HIV-AIDS dari 1,5 juta orang menjadi 1,1 juta orang. Terapi HIV-AIDS juga berguna untuk mencegah penularan HIV kepada pasangan seksual maupun penularan HIV dari ibu ke anak [2].

Permasalahan pada penyakit HIV-AIDS di dunia kesehatan ini selain dikarenakan belum terdapat obat maupun vaksin yang dapat menyembuhkan penderita HIV-AIDS sepenuhnya, juga dikarenakan semakin meningkatnya penyebaran infeksi HIV. Penyebaran dari penyakit HIV-AIDS ini menjadi suatu tantangan bagi para ilmuan baik di bidang kesehatan maupun analisis, yaitu untuk memberikan solusi terkait permasalahan di dunia kesehatan khususnya pada penyebaran penyakit HIV-AIDS.

Seiring berkembangnya ilmu pengetahuan di masa ini telah diperoleh suatu ilmu dibidang matematika yang dapat digunakan untuk merepresentasikan permasalahan yang ada dalam kehidupan sehari-hari ke dalam pernyataan matematika, hasil yang diperoleh dari proses representasi ini disebut 
model matematika [3]. Model matematika yang dihasilkan mencakup beberapa bidang keilmuan, yakni fisika, ekonomi, kesehatan, dan sebagainya.

Model matematika yang digunakan pada penelitian ini merupakan model di bidang kesehatan, yakni penyebaran penyakit HIV-AIDS. Penelitian ini merupakan pengembangan dari penelitian yang telah dilakukan oleh Haryanto, Kusumastuti dan Prihandono [4] yang membentuk total populasi menjadi tiga subpopulasi, yaitu Susceptible atau negatif HIV, Infected atau positif HIV, dan AIDS Case atau kasus AIDS yang disebut model SIA dengan populasi tertutup, kemudian penelitian yang telah dilakukan oleh Soleh, Fatmasari dan Muhaijir [5] yang menambahkan satu subpopulasi yaitu Treatment (Terapi) sehingga model yang digunakan adalah model SITA dan populasi terbuka artinya terdapat pengaruh migrasi (imigrasi dan emigrasi) tanpa melihat pengaruh infeksi pada individu imigran dan subpopulasi orang dengan HIV-AIDS (ODHA) yang melakukan terapi. Berdasarkan pernyataan dari Kementrian Kesehatan RI terdapat imigran yang terinfeksi HIV kemudian ODHA juga mendapatkan terapi [6], sehingga pada penelitian ini terdapat modifikasi model dengan penambahan parameter baru, yakni laju infeksi pada individu imigran dan laju ODHA yang melakukan terapi.

\section{MODEL MATEMATIKA}

Total populasi $(N)$ pada model matematika dampak terapi terhadap penyebaran penyakit HIVAIDS dengan populasi terbuka ini dikelompokkan menjadi empat subpopulasi: Susceptible $(S)$ merupakan subpopulasi manusia yang rentan terhadap infeksi HIV atau negatif HIV, Infected (I) merupakan subpopulasi manusia yang telah terinfeksi HIV atau positif HIV, Treatment $(T)$ merupakan subpopulasi positif HIV yang melakukan terapi HIV-AIDS, dan AIDS patients $(A)$ merupakan subpopulasi positif HIV yang terdiagnosa menjadi AIDS atau ODHA sehingga disebut model SITA. Asumsi-asumsi yang diberikan pada model SITA ini, yakni sebagai berikut:

1. Total populasi $(N)$ konstan,

2. Populasi bersifat terbuka, sehingga terdapat migrasi (imigrasi dan emigrasi). Dengan demikian transisi populasi dipengaruhi kelahiran alami, kematian alami, imigrasi dan emigrasi dengan laju masing-masing $\Lambda, k, b$, dan $m$ yang konstan,

3. Imigrasi dan kelahiran alami hanya terjadi pada subpopulasi negatif HIV. Sedangkan emigrasi dan kematian alami terjadi di setiap subpopulasi,

4. Terdapat kematian karena AIDS pada ODHA dengan laju $\delta$,

5. Infeksi terjadi karena adanya kontak antara subpopulasi negatif HIV dengan positif HIV,

6. Penularan infeksi yang terjadi hanya melalui kontak seksual,

7. Tidak ada penularan infeksi melalui subpopulasi terapi HIV-AIDS dan ODHA, artinya tidak terjadi kontak antara subpopulasi terapi HIV-AIDS dengan negatif HIV dan ODHA dengan negatif HIV. Diasumsikan subpopulasi terapi HIV-AIDS dan ODHA bersifat pasif karena telah menurunnya sistem kekebalan tubuh kemudian telah mengetahui dampak yang ditimbulkan oleh penyakit HIV-AIDS,

8. Infeksi yang terjadi pada subpopulasi negatif HIV dipengaruhi oleh proporsi dari subpopulasi positif HIV dengan total populasi $\left(\frac{I}{N}\right)$ terhadap rata-rata kontak yang terjadi pada individu lokal dengan laju infeksi lokal dan rata-rata kontak yang terjadi pada individu imigran dengan laju infeksi individu imigran terhadap subpopulasi negatif HIV dengan laju masing-masing $c_{1} \beta_{1}$ dan $c_{2} \beta_{2}$ dengan $\beta_{2}<\beta_{1}$ dan $c_{2}<c_{1}$,

9. Laju transisi subpopulasi positif HIV dan terapi HIV-AIDS menjadi ODHA secara terurut adalah $\alpha_{1}$ dan $\alpha_{2}$ dengan $\alpha_{2}<\alpha_{1}$,

10. Terapi HIV-AIDS dilakukan terhadap subpopulasi positif HIV dan ODHA dengan laju masingmasing secara terurut $\theta$ dan $u$. 
Berdasarkan asumsi-asumsi tersebut diperoleh transisi dari keempat subpopulasi dalam bentuk sistem persamaan diferensial nonlinear, yakni sebagai berikut:

$$
\begin{aligned}
& \frac{d S}{d t}=\Lambda+b-\left(c_{1} \beta_{1}+c_{2} \beta_{2}\right) S \frac{I}{N}-(k+m) S, \\
& \frac{d I}{d t}=\left(c_{1} \beta_{1}+c_{2} \beta_{2}\right) S \frac{I}{N}-\theta I-\alpha_{1} I-(k+m) I, \\
& \frac{d T}{d t}=\theta I+u A-\alpha_{2} T-(k+m) T, \\
& \frac{d A}{d t}=\alpha_{1} I+\alpha_{2} T-u A-(k+m+\delta) A,
\end{aligned}
$$

dengan

$N$ : total populasi,

$\Lambda$ : kelahiran alami pada subpopulasi negatif HIV,

$b$ : laju imigrasi pada subpopulasi negatif HIV,

$k \quad$ : laju kematian alami,

$m$ : laju emigrasi,

$\beta_{1}$ : laju infeksi yang terjadi antara individu lokal pada subpopulasi negatif HIV dengan positif HIV,

$\beta_{2}$ : laju infeksi yang terjadi antara individu imigran pada subpopulasi negatif HIV dengan positif HIV,

$c_{1}$ : rata-rata kontak yang terjadi antara individu lokal pada subpopulasi negatif HIV dengan positif HIV,

$c_{2}$ : rata-rata kontak yang terjadi antara individu imigran pada subpopulasi negatif HIV dengan positif HIV,

$\theta \quad$ : laju subpopulasi positif HIV melakukan terapi HIV-AIDS,

$\alpha_{1}$ : laju transisi subpopulasi positif HIV terdiagnosa menjadi ODHA,

$\alpha_{2}$ : laju transisi subpopulasi terapi HIV-AIDS terdiagnosa menjadi ODHA,

$\delta \quad$ : laju kematian karena ODHA,

$u \quad$ : laju subpopulasi ODHA melakukan terapi HIV-AIDS.

Kemudian $\Lambda, b, k, m, \beta_{1}, \beta_{2}, \alpha_{1}, \alpha_{2}, \delta>0$ dan $c_{1}, c_{2}, \theta, u \geq 0$, dengan $N=S+I+T+A$.

\section{TITIK KESETIMBANGAN}

Titik kesetimbangan merupakan suatu titik yang tetap (konstan) dan tidak berubah terhadap waktu. Titik kesetimbangan pada sistem (1) merupakan solusi-solusi yang konstan walaupun waktu berganti [7]. Titik kesetimbangan dapat ditentukan menggunakan definisi berikut:

Definisi 1 [8] Titik $\mathbf{E}^{*} \in \mathbb{R}^{n}$ disebut titik kesetimbangan dari sistem (1) jika $\mathbf{f}\left(\mathbf{E}^{*}\right)=\mathbf{0}$.

Terdapat dua macam titik kesetimbangan pada penyebaran penyakit HIV-AIDS, yakni sebagai berikut:

1. Titik Kesetimbangan Bebas Penyakit

Titik kesetimbangan bebas penyakit $\left(\mathbf{E}_{1}\right)$ terjadi apabila tidak terdapat infeksi pada subpopulasi negatif HIV, artinya tidak ada kontak yang terjadi antara subpopulasi negatif HIV dengan positif HIV, akibatnya subpopulasi positif HIV tidak akan meningkat sehingga pada suatu waktu subpopulasi terinfeksi HIV, terapi HIV-AIDS, dan ODHA akan hilang atau habis, sehingga diperoleh

$$
I=T=A=0 .
$$

Selanjutnya dengan mensubstitusikan persamaan (2) ke sistem (1) diperoleh

$$
0=\Lambda+b-(k+m) S,
$$




$$
S=\frac{\Lambda+b}{k+m}
$$

Lebih lanjut diperoleh titik kesetimbangan bebas penyakit sebagai berikut

$$
\mathbf{E}_{1}=\left(S^{*}, I^{*}, T^{*}, A^{*}\right)=\left(\frac{\Lambda+b}{k+m}, 0,0,0\right) \text {. }
$$

2. Titik Kesetimbangan Endemik Penyakit

Titik kesetimbangan endemik penyakit $\left(\mathbf{E}_{2}\right)$ terjadi apabila adanya kontak antara individu pada subpopulasi negatif HIV dengan individu pada subpopulasi positif HIV, artinya subpopulasi positif HIV, subpopulasi terapi HIV-AIDS, dan subpopulasi ODHA akan tetap ada. Sehingga dengan menyederhanakan sistem (1) diperoleh titik kesetimbangan endemik penyakit $\mathbf{E}_{2}=\left(S^{* *}, I^{* *}, T^{* *}, A^{* *}\right)$ sebagai berikut:

$$
\begin{aligned}
S^{* *} & =\frac{N\left(\theta+\alpha_{1}+k+m\right)}{\left(c_{1} \beta_{1}+c_{2} \beta_{2}\right)}, \\
I^{* *} & =\frac{(\Lambda+b)\left(c_{1} \beta_{1}+c_{2} \beta_{2}\right)-N(k+m)\left(\theta+\alpha_{1}+k+m\right)}{\left(c_{1} \beta_{1}+c_{2} \beta_{2}\right)\left(\theta+\alpha_{1}+k+m\right)}, \\
T^{* *} & =\frac{\left(u\left(\alpha_{1}+\theta\right)+\theta(k+m+\delta)\right)\left((\Lambda+b)\left(c_{1} \beta_{1}+c_{2} \beta_{2}\right)-N(k+m)\left(\theta+\alpha_{1}+k+m\right)\right)}{\left(c_{1} \beta_{1}+c_{2} \beta_{2}\right)\left(\theta+\alpha_{1}+k+m\right)\left(\alpha_{2}(k+m+\delta)+\delta(k+m)+(k+m)^{2}+u(k+m)\right)}, \\
A^{* *} & =\frac{\left(\alpha_{1}\left(\alpha_{2}+k+m\right)+\alpha_{2} \theta\right)\left((\Lambda+b)\left(c_{1} \beta_{1}+c_{2} \beta_{2}\right)-N(k+m)\left(\theta+\alpha_{1}+k+m\right)\right)}{\left(c_{1} \beta_{1}+c_{2} \beta_{2}\right)\left(\theta+\alpha_{1}+k+m\right)\left(\alpha_{2}(k+m+\delta)+\delta(k+m)+(k+m)^{2}+u(k+m)\right)} .
\end{aligned}
$$

\section{Angka Reproduksi Efektif}

Angka reproduksi efektif $\left(R_{I}\right)$ digunakan untuk mengukur rata-rata jumlah infeksi baru yang disebabkan oleh satu individu terinfeksi HIV dalam suatu populasi [9] dengan program terapi HIVAIDS digunakan sebagai strategi kontrol. Faktor yang menyebabkan infeksi pada subpopulasi negatif HIV adalah laju infeksi dari individu pada subpopulasi positif HIV sehingga diperoleh

$$
R_{I}=\frac{(\Lambda+b)\left(c_{1} \beta_{1}+c_{2} \beta_{2}\right)}{N(k+m)\left(\theta+\alpha_{1}+k+m\right)} .
$$

\section{ANALISIS KESTABILAN}

Sistem (1) merupakan sistem persamaan diferensial nonlinear, sehingga untuk menentukan kestabilan pada titik kesetimbangan perlu pelinearisasian, karena untuk mengetahui kestabilan masingmasing titik kesetimbangan model dapat menggunakan sistem persamaan yang telah dilinierisasikan. Dengan melinearisasikan sistem (1) diperoleh matriks Jacobian berikut

$$
\mathbf{J}=\left[\begin{array}{cccc}
-\left(c_{1} \beta_{1}+c_{2} \beta_{2}\right) \frac{I}{N}-(k+m) & -\left(c_{1} \beta_{1}+c_{2} \beta_{2}\right) \frac{S}{N} & 0 & 0 \\
\left(c_{1} \beta_{1}+c_{2} \beta_{2}\right) \frac{I}{N} & \left(c_{1} \beta_{1}+c_{2} \beta_{2}\right) \frac{S}{N}-\left(\theta+\alpha_{1}+k+m\right) & 0 & 0 \\
0 & \theta & -\left(\alpha_{2}+k+m\right) & u \\
0 & \alpha_{1} & \alpha_{2} & -(u+k+m+\delta)
\end{array}\right] .
$$

Kemudian dengan mereduksi (6) dengan operasi baris elementer model segitiga atas diperoleh matriks Jacobian tereduksi sebagai berikut:

$$
\mathbf{J}_{R}=\left[\begin{array}{cccc}
-a_{11} & -a_{12} & 0 & 0 \\
0 & -a_{22} & 0 & 0 \\
0 & 0 & -a_{33} & u \\
0 & 0 & 0 & -a_{44}
\end{array}\right],
$$


dengan

$a_{11}=\left(c_{1} \beta_{1}+c_{2} \beta_{2}\right) \frac{I}{N}+(k+m)$,

$a_{12}=\frac{\left(c_{1} \beta_{1}+c_{2} \beta_{2}\right) S}{N}$,

$a_{22}=\frac{\left(I\left(c_{1} \beta_{1}+c_{2} \beta_{2}\right)+N(k+m)\right)\left(\theta+\alpha_{1}+k+m\right)-(k+m)\left(c_{1} \beta_{1}+c_{2} \beta_{2}\right) S}{I\left(c_{1} \beta_{1}+c_{2} \beta_{2}\right)+N(k+m)}$,

$a_{33}=\alpha_{1}+k+m$,

$a_{44}=\frac{\alpha_{2}(k+m+\delta)+(k+m)(u+k+m+\delta)}{\alpha_{2}+k+m}$.

Nilai eigen pada model penyebaran HIV-AIDS dengan terapi dan populasi terbuka diperoleh apabila $\operatorname{det}\left(\mathbf{J}_{\mathrm{R}}-\lambda \mathbf{I}\right)=0$ dengan $\mathbf{J}_{R}$ merupakan matriks (7) dan I merupakan matriks identitas, sehingga diperoleh

$$
\left(-a_{11}-\lambda\right)\left(-a_{22}-\lambda\right)\left(-a_{33}-\lambda\right)\left(-a_{44}-\lambda\right)=0
$$

Lebih lanjut diperoleh nilai eigen sebagai berikut

$$
\begin{aligned}
& \lambda_{1}=-\left(\left(c_{1} \beta_{1}+c_{2} \beta_{2}\right) \frac{I}{N}+(k+m)\right), \\
& \lambda_{2}=-\left(\frac{\left(I\left(c_{1} \beta_{1}+c_{2} \beta_{2}\right)+N(k+m)\right)\left(\theta+\alpha_{1}+k+m\right)-(k+m)\left(c_{1} \beta_{1}+c_{2} \beta_{2}\right) S}{I\left(c_{1} \beta_{1}+c_{2} \beta_{2}\right)+N(k+m)}\right), \\
& \lambda_{3}=-\left(\alpha_{1}+k+m\right), \\
& \lambda_{4}=-\left(\frac{\alpha_{2}(k+m+\delta)+(k+m)(u+k+m+\delta)}{\alpha_{2}+k+m}\right) .
\end{aligned}
$$

Selanjutnya dengan mensubstitusikan titik kesetimbangan bebas penyakit ( $\left.\mathbf{E}_{1}\right)$ dan titik kesetimbangan endemik penyakit $\left(\mathbf{E}_{2}\right)$ ke nilai eigen (8) akan ditentukan kestabilan pada masingmasing titik kesetimbangan. Berdasarkan sifat stabilitas sistem oleh Boyce dan DiPrima [10] diperoleh solusi pada titik kesetimbangan bebas penyakit dan endemik penyakit dikatakan stabil asimtotik jika nilai eigen $(\lambda)$ pada titik kesetimbangan bernilai negatif artinya $\lambda_{i}<0$, untuk $i=1,2,3,4$.

1. Kestabilan pada Titik Kesetimbangan Bebas Penyakit

Kestabilan pada titik kesetimbangan bebas penyakit $\left(\mathbf{E}_{1}\right)$ diperoleh dengan mensubstitusikan (3) ke (8) sehingga lebih lanjut diperoleh nilai eigen pada titik kesetimbangan bebas penyakit sebagai berikut:

$$
\begin{aligned}
& \lambda_{1 \mathbf{E}_{1}}=-(k+m), \\
& \lambda_{2 \mathbf{E}_{1}}=-\left(\frac{N(k+m)\left(\theta+\alpha_{1}+k+m\right)-(\Lambda+b)\left(c_{1} \beta_{1}+c_{2} \beta_{2}\right)}{N(k+m)}\right), \\
& \lambda_{3 \mathbf{E}_{1}}=-\left(\alpha_{1}+k+m\right), \\
& \lambda_{4 \mathbf{E}_{1}}=-\left(\frac{\alpha_{2}(k+m+\delta)+(k+m)(u+k+m+\delta)}{\alpha_{2}+k+m}\right) .
\end{aligned}
$$

Berdasarkan sifat stabilitas sistem, kestabilan pada titik kesetimbangan bebas penyakit $\left(\mathbf{E}_{1}\right)$ akan stabil asimtotik jika nilai eigen (9), yakni $\lambda_{i \mathbf{E}_{1}}$ untuk $i=1,2,3,4$ bernilai negatif dengan memenuhi salah satu dari dua kondisi berikut:

1) Kondisi pertama

Berdasarkan nilai eigen (9) pada titik kesetimbangan bebas penyakit diperoleh $\lambda_{1 \mathbf{E}_{1}}, \lambda_{3 \mathbf{E}_{1}}, \lambda_{4 \mathbf{E}_{1}}<0$, selanjutnya berdasarkan sifat stabilitas sistem akan ditunjukkan nilai $\lambda_{2 \mathbf{E}_{1}}$ negatif. Perhatikan bahwa pada titik kesetimbangan bebas penyakit akan stabil asimtotik jika kontak antara individu negatif HIV dengan individu positif HIV tidak ada, sehingga $c_{1}=c_{2}=0$ diperoleh 


$$
\lambda_{2 \mathbf{E}_{1}}=-\left(\theta+\alpha_{1}+k+m\right)<0,
$$

akibatnya $\lambda_{2 \mathbf{E}_{1}}$ bernilai negatif, maka titik kesetimbangan bebas penyakit stabil asimtotik.

2) Kondisi kedua

Teorema 2 [9] Titik kesetimbangan bebas penyakit pada sistem (1) adalah stabil asimtotik jika $R_{I}<1$ dan tidak stabil jika $R_{I}>1$.

\section{Bukti}

Berdasarkan (5) diketahui angka reproduksi efektif dari positif HIV adalah $R_{I}=\frac{(\Lambda+b)\left(c_{1} \beta_{1}+c_{2} \beta_{2}\right)}{N(k+m)\left(\theta+\alpha_{1}+k+m\right)}$, dengan $R_{I}<1$ untuk memperoleh nilai dari $\lambda_{2 \mathbf{E}_{1}}$ negatif akan ditunjukkan $N(k+m)\left(\theta+\alpha_{1}+k+m\right)-(\Lambda+b)\left(c_{1} \beta_{1}+c_{2} \beta_{2}\right)>0$, berdasarkan angka reproduksi efektif dari positif HIV $\left(R_{I}\right)$ diperoleh

$$
\begin{aligned}
\frac{(\Lambda+b)\left(c_{1} \beta_{1}+c_{2} \beta_{2}\right)}{N(k+m)\left(\theta+\alpha_{1}+k+m\right)} & <1, \\
(\Lambda+b)\left(c_{1} \beta_{1}+c_{2} \beta_{2}\right) & <N(k+m)\left(\theta+\alpha_{1}+k+m\right), \\
N(k+m)\left(\theta+\alpha_{1}+k+m\right)-(\Lambda+b)\left(c_{1} \beta_{1}+c_{2} \beta_{2}\right) & >0 .
\end{aligned}
$$

Sehingga terbukti, titik kesetimbangan bebas penyakit stabil asimtotik jika $R_{I}<1$ dan tidak stabil jika $R_{I}>1$.

2. Kestabilan pada Titik Kesetimbangan Endemik Penyakit

Kestabilan pada titik kesetimbangan endemik penyakit $\left(\mathbf{E}_{2}\right)$ diperoleh dengan mensubstitusikan (4) ke (7) sehingga lebih lanjut diperoleh nilai eigen pada titik kesetimbangan endemik penyakit sebagai berikut:

$$
\begin{aligned}
& \lambda_{1 \mathbf{E}_{2}}=-\left(\frac{(\Lambda+b)\left(c_{1} \beta_{1}+c_{2} \beta_{2}\right)}{N\left(\theta+\alpha_{1}+k+m\right)}\right), \\
& \lambda_{2 \mathbf{E}_{2}}=-\left(\left(1-\frac{N(k+m))\left(\theta+\alpha_{1}+k+m\right)}{(\Lambda+b)\left(c_{1} \beta_{1}+c_{2} \beta_{2}\right)}\right)\left(\theta+\alpha_{1}+k+m\right)\right), \\
& \lambda_{3 \mathbf{E}_{2}}=-\left(\alpha_{1}+k+m\right), \\
& \lambda_{4 \mathbf{E}_{2}}=-\left(\frac{\alpha_{2}(k+m+\delta)+(k+m)(u+k+m+\delta)}{\alpha_{2}+k+m}\right) .
\end{aligned}
$$

Berdasarkan sifat stabilitas sistem, kestabilan pada titik kesetimbangan endemik penyakit $\left(\mathbf{E}_{2}\right)$ akan stabil asimtotik jika nilai eigen (10), yakni $\lambda_{i \mathbf{E}_{2}}$ untuk $i=1,2,3,4$ bernilai negatif dengan memenuhi teorema berikut:

Teorema 3 [9] Titik kesetimbangan endemik penyakit pada sistem (1) adalah stabil asimtotik jika $R_{I}>1$.

\section{Bukti}

Berdasarkan nilai eigen (10) pada titik kesetimbangan endemik penyakit diperoleh $\lambda_{1 \mathrm{E}_{2}}, \lambda_{3 \mathrm{E}_{2}}$, $\lambda_{4 \mathrm{E}_{2}}<0$, kemudian berdasarkan sifat stabilitas sistem akan ditunjukkan nilai dari $\lambda_{2 \mathrm{E}_{2}}$ negatif.

Diketahui $R_{I}>1$ untuk memperoleh nilai dari $\lambda_{2 \mathrm{E}_{2}}$ negatif, maka ditunjukkan $\underline{\left(1-\frac{N(k+m))\left(\theta+\alpha_{1}+k+m\right)}{(\Lambda+b)\left(c_{1} \beta_{1}+c_{2} \beta_{2}\right)}\right)>0 \text { sehingga diperoleh }}$ 


$$
\begin{gathered}
\frac{(\Lambda+b)\left(c_{1} \beta_{1}+c_{2} \beta_{2}\right)}{N(k+m)\left(\theta+\alpha_{1}+k+m\right)}>1, \\
\frac{N(k+m)\left(\theta+\alpha_{1}+k+m\right)}{(\Lambda+b)\left(c_{1} \beta_{1}+c_{2} \beta_{2}\right)}<1, \\
\left(1-\frac{N(k+m)\left(\theta+\alpha_{1}+k+m\right)}{(\Lambda+b)\left(c_{1} \beta_{1}+c_{2} \beta_{2}\right)}\right)>0 .
\end{gathered}
$$

Akibatnya $\lambda_{2 \mathbf{E}_{2}}<0$, maka kestabilan pada titik kesetimbangan endemik penyakit $\left(\mathbf{E}_{2}\right)$ adalah stabil asimtotik.

\section{SIMULASI}

Berdasarkan data dari Kementerian Kesehatan RI dan Badan Pusat Statistik diperoleh syarat nilai awal pada populasi serta subpopulasi yang digunakan dalam model matematika ini, yakni sebagai berikut $N(0)=265.015 .300, S(0)=264.709 .003, I(0)=146.422, T(0)=87.892, A(0)=71.983$. Kemudian nilai parameter-parameter yang digunakan pada penelitian ini diperoleh dari beberapa sumber, yakni tercantum pada Tabel 1, untuk parameter laju kelahiran alami $(\Lambda)$ dan imigrasi $(b)$ digunakan data pada tahun 2018.

Tabel 1 Nilai Parameter pada Model Matematika Penyebaran Penyakit HIV-AIDS dengan Terapi dan Populasi Terbuka

\begin{tabular}{ccc}
\hline Parameter & Nilai & Sumber \\
\hline$\Lambda$ & 4.472 .300 & Badan Pusat Statistik [11] \\
$b$ & 14.391 .816 & Badan Pusat Statistik [12] \\
$k$ & 0,0147 & Soleh et al. [5] \\
$m$ & 0,008 & Badan Pusat Statistik [13] \\
$\beta_{1}$ & 0,4419 & Soleh et al. [5] \\
$\beta_{2}$ & $4 \times 10^{-8}$ & Kementerian Kesehatan RI [6] \\
$c_{1}$ & 2 & Asumsi \\
$c_{2}$ & 1 & Asumsi \\
$\theta$ & 0,4537 & Soleh et al. [5] \\
$\alpha_{1}$ & 0,654 & Soleh et al. [5] \\
$\alpha_{2}$ & 0,0016 & Soleh et al. [5] \\
$\delta$ & 0,163 & Soleh et al. [5] \\
$u$ & 0,1 & Waziri et al. [14] \\
\hline
\end{tabular}

1. Simulasi Model pada Titik Kesetimbangan Bebas Penyakit $\left(\mathbf{E}_{1}\right)$

Simulasi model matematika dampak terapi pada penyebaran penyakit HIV-AIDS dengan populasi terbuka untuk titik kesetimbangan bebas penyakit $\left(\mathbf{E}_{1}\right)$ stabil asimtotik jika memenuhi salah satu dari dua kondisi berikut, yakni kondisi pertama tidak terdapat kontak yang menyebabkan individu pada subpopulasi positif HIV dengan individu pada subpopulasi negatif HIV terjadi $\left(c_{1}=c_{2}=0\right)$ atau kondisi kedua $R_{I}<1$ dengan $R_{I}=\frac{(\Lambda+b)\left(c_{1} \beta_{1}+c_{2} \beta_{2}\right)}{N(k+m)\left(\theta+\alpha_{1}+k+m\right)}$. Berdasarkan nilai-nilai parameter pada Tabel 1 diketahui terdapat kontak yang terjadi antara individu pada subpopulasi positif HIV dengan individu pada subpopulasi negatif HIV, kemudian jika disubstitusikan pada $R_{I}=\frac{(\Lambda+b)\left(c_{1} \beta_{1}+c_{2} \beta_{2}\right)}{N(k+m)\left(\theta+\alpha_{1}+k+m\right)}$ diperoleh $R_{I}=2,4516>1$ artinya titik kesetimbangan bebas penyakit pada sistem (1) tidak stabil karena tidak memenuhi salah satu dari dua kondisi tersebut. 
2. Simulasi Model pada Titik Kesetimbangan Endemik Penyakit $\left(\mathbf{E}_{2}\right)$

Simulasi untuk model matematika pada titik kesetimbangan endemik penyakit $\left(\mathbf{E}_{2}\right)$ stabil asimtotik apabila memenuhi $R_{I}>1$. Berdasarkan nilai-nilai parameter pada Tabel 1 diperoleh $R_{I}=2,4517$ artinya sistem (1) pada titik kesetimbangan endemik penyakit stabil asimtotik, akibatnya solusi masing-masing subpopulasi menuju ke titik kesetimbangan endemik penyakit $\mathbf{E}_{2}=\left(S^{* *}, I^{* *}, T^{* *}\right.$, $\left.A^{* *}\right)=\left(3,3896 \times 10^{8}, 9,8812 \times 10^{6}, 2,8412 \times 10^{8}, 2,421 \times 10^{7}\right)$ diperoleh hasil simulasi pada kondisi endemik penyakit, yakni sebagai berikut:

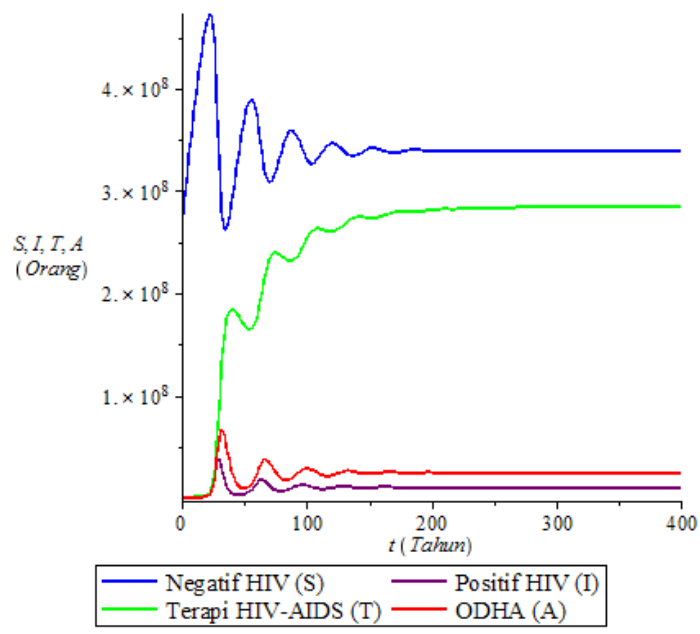

Gambar 1 Grafik Penyebaran Penyakit HIV-AIDS dengan Terapi dan Populasi Terbuka pada Titik Kesetimbangan Endemik Penyakit dengan $R_{I}=2,4517$

Gambar 1 menunjukkan grafik dari masing-masing subpopulasi, yakni subpopulasi negatif HIV, positif HIV, terapi HIV-AIDS, dan ODHA. Pada subpopulasi negatif HIV jumlah populasi mengalami kenaikan akibat kelahiran alami dan adanya imigrasi, kemudian mengalami penurunan akibat kematian alami, emigrasi dan transisi pada individu negatif HIV menjadi positif HIV hingga selanjutnya pada waktu $t \rightarrow \infty$ akan konstan menuju 3,3896 $\times 10^{8}$ orang. Sedangkan jumlah populasi pada subpopulasi terapi HIV-AIDS terus meningkat yang diakibatkan oleh transisi dari subpopulasi positif HIV dan ODHA yang melakukan terapi HIV-AIDS dan menurun akibat kematian alami, emigrasi dan terdiagnosanya individu-individu pada subpopulasi terapi HIV-AIDS menjadi ODHA sehingga mengakibatkan meningkatnya subpopulasi ODHA. Kemudian pada subpopulasi positif HIV dan ODHA menunjukkan bahwa jumlah populasi yang relatif stabil, untuk subpopulasi positif HIV meningkat karena ada transisi pada subpopulasi negatif HIV menjadi positif HIV dan menurun akibat kematian alami, emigrasi, transisi dari positif HIV yang terdiagnosa menjadi ODHA sehingga mengakibatkan meningkatnya subpopulasi ODHA, serta adanya individu-individu pada subpopulasi positif HIV yang melakukan terapi HIV-AIDS. Sedangkan subpopulasi ODHA menurun akibat kematian alami, kematian akibat penyakit AIDS, emigrasi, dan adanya ODHA yang melakukan terapi HIV-AIDS. Namun jumlah subpopulasi positif HIV, terapi HIV-AIDS dan ODHA pada waktu $t \rightarrow \infty$ akan konstan dan secara terurut menuju $9,8812 \times 10^{6}$ orang, $2,8412 \times 10^{8}$ orang dan $2,421 \times 10^{7}$ orang, sehingga pada titik kesetimbangan endemik penyakit subpopulasi HIV dan ODHA tetap ada artinya hubungan kontak yang mengakibatkan menyebarnya virus HIV terus terjadi.

Selanjutnya merupakan perbandingan hasil simulasi penyebaran penyakit HIV-AIDS dengan terapi dan tanpa terapi. Simulasi penyebaran penyakit HIV-AIDS tanpa terapi terjadi apabila $\theta=u=0$, sehingga diperoleh perbandingan hasil simulasi sebagai berikut: 


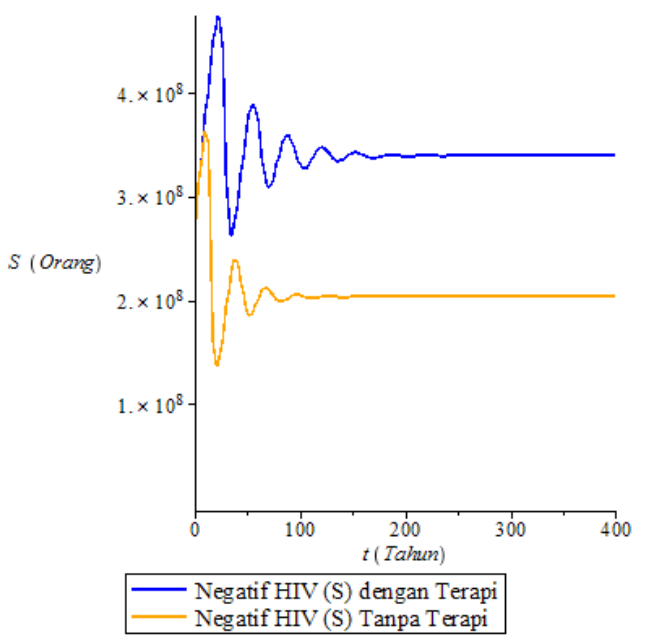

(a) Subpopulasi Negatif HIV (S)

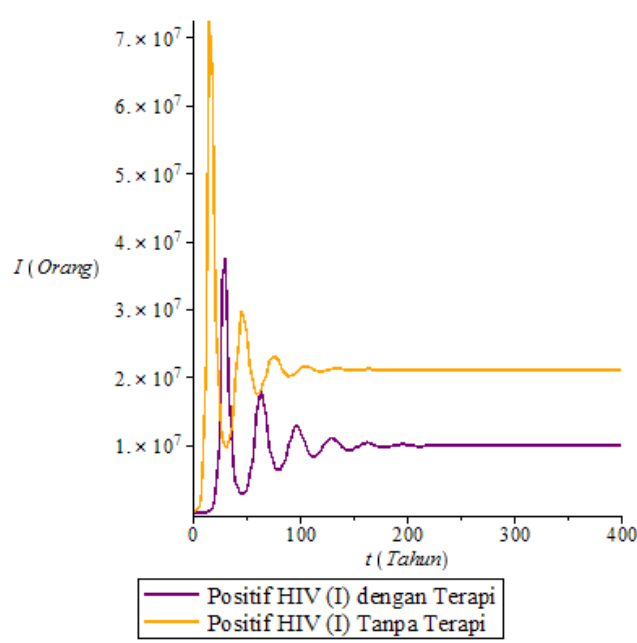

(b) Subpopulasi Positif HIV (I)

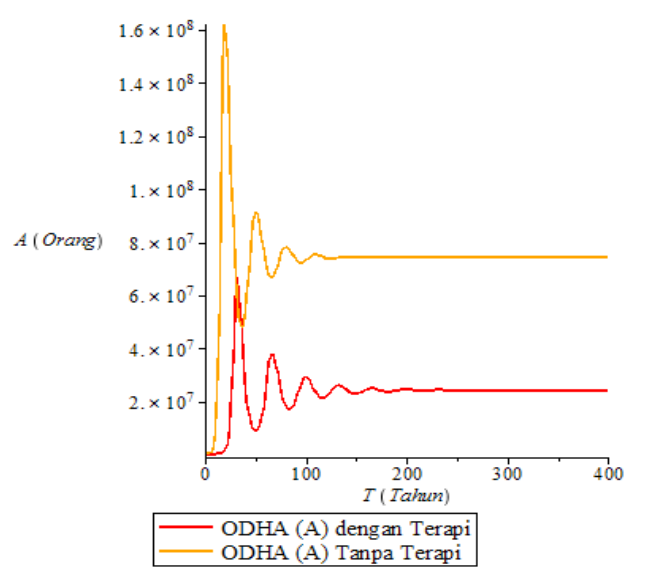

(c) Subpopulasi ODHA $(A)$

Gambar 2 Perbandingan Penyebaran Penyakit HIV-AIDS dengan Terapi dan Tanpa Terapi

Berdasarkan Gambar 2a-2c diperoleh bahwa kontrol terapi pada penyebaran penyakit HIV-AIDS memberikan pengaruh positif dalam mempertahankan jumlah subpopulasi negatif HIV, memperlambat penyebaran infeksi HIV-AIDS, serta mengurangi jumlah subpopulasi positif HIV, subpopulasi ODHA, dan kematian yang diakibatkan oleh penyakit HIV-AIDS.

\section{KESIMPULAN}

Dampak dari terapi HIV-AIDS pada penyebaran penyakit HIV-AIDS berdasarkan hasil simulasi memberikan pengaruh positif dalam mempertahankan jumlah subpopulasi negatif HIV, memperlambat penyebaran infeksi, serta mengurangi jumlah subpopulasi positif HIV, subpopulasi ODHA, dan kematian akibat HIV-AIDS.

Hasil yang diperoleh berdasarkan analisis pada penelitian ini menunjukkan bahwa penyebaran penyakit HIV-AIDS akan habis apabila, pertama jika tidak terjadinya kontak antara individu positif HIV dengan negatif HIV atau kedua memenuhi $R_{I}<1$. Namun penyebaran penyakit HIV-AIDS akan tetap ada jika tidak memenuhi kedua kondisi tersebut atau $R_{I}>1$. 


\section{DAFTAR PUSTAKA}

[1] Sutimin, Imamudin. Model Dinamik Penularan Human Immunodificiency Virus (HIV). Jurnal Sains dan Matematika. 2009; 17(1):8-16.

[2] Karyadi TH. Keberhasilan Pengobatan Antiretroviral (ARV). Jakarta: Departemen Ilmu Penyakit Dalam. 2017.

[3] Widowati, Sutimin. Pemodelan Matematika. Semarang: Universitas Diponegoro. 2007.

[4] Haryanto D, Kusumastuti N, Prihandono B. Pemodelan Matematika dan Analisis Kestabilan Model pada Penyebaran HIV-AIDS. Buletin Ilmiah Mat. Stat. dan Terapan (Bimaster). 2015; 04(2):101-110.

[5] Soleh M, Fatmasari D, Muhaijir MN. Model Matematika Penyebaran Penyakit HIV/AIDS dengan Terapi pada Populasi Terbuka. Jurnal Sains Matematika dan Statistika. 2017; 3(1);2028.

[6] Kementerian Kesehatan Republik Indonesia. Laporan Perkembangan HIV AIDS \& Infeksi Menular Seksual (IMS) Triwulan III Tahun 2018. Jakarta: KemenKes RI. 2018.

[7] Wiggins S. Introduction to Applied Nonlinear Dinamical System and Chaos. Second Edition. New York: Springer-verlag. 1990.

[8] Perko L. Differential Equations and Dynamical Systems. Third Edition. New York: SpringerVerlag. 2001.

[9] Marsudi, Marjono, Andari A. Modelling the Effect of Screening and Therapy on the Dynamics of HIV Transmission in Malang. Malang: University of Brawijaya. 2015.

[10] Boyce WE, DiPrima RC. Elementary Differential Equations and Boundary Value Problems. Seventh Edition. United State of America: John Wiley \& Sons, Inc. 2009.

[11] Badan Pusat Statistik. Proyeksi Penduduk Indonesia 2015-2045 Hasil SUPAS 2015. Jakarta: BPS. 2018.

[12] Badan Pusat Statistik. Perkembangan Pariwisata dan Transportasi Nasional November 2018. Jakarta: BPS. 2019.

[13] Badan Pusat Statistik. Kajian Migrasi Internasional. Jakarta: BPS. 2018.

[14] Waziri AS, Massawe ES, Makinde OD. Mathematical Modelling of HIV/AIDS Dynamics with Treatment and Vertical Transmition. Applied Mathematics. 2012; 2(3):77-89.

$\begin{array}{ll}\text { FERI HARIANTO } & \begin{array}{l}\text { : Jurusan Matematika FMIPA UNTAN, Pontianak } \\ \text { feriharianto@student.untan.ac.id }\end{array} \\ \text { EVI NOVIANI } & \begin{array}{l}\text { : Jurusan Matematika FMIPA UNTAN, Pontianak } \\ \text { evi noviani@ math.untan.ac.id }\end{array} \\ \text { YUDHI } & \begin{array}{l}\text { : Jurusan Matematika FMIPA UNTAN, Pontianak } \\ \text { yudhi@ @ath.untan.ac.id }\end{array}\end{array}$

